\title{
Trends in Demand of Urban Surface Water Extractions and in Situ Use Functions
}

\author{
E. S. van der Meulen ${ }^{1,2} \cdot$ N. B. Sutton ${ }^{2} \cdot$ F. H. M. van de Ven ${ }^{1,3} \cdot$ P. R. van Oel ${ }^{4} \cdot$ \\ H. H. M. Rijnaarts ${ }^{2}$
}

Received: 8 June 2020 / Accepted: 26 October 2020 /

Published online: 6 November 2020

(C) The Author(s) 2020

\begin{abstract}
Scientific literature currently lacks comprehensive understanding of urban surface water use functions. This hampers sound analysis of the demand and potential supply of these functions. This study provides a comprehensive overview of potential use functions, by integrating knowledge from ecosystem services and integrated urban water management fields. Analysis of water-related management plans for Toronto and Amsterdam shows that surface water is currently being used for a variety of functions related to nutrition, energy, water regulation, recreation, symbolic use, transportation and floating buildings. Notably, many use functions involve in situ use, rather than water extractions. Interviewed water managers and spatial planners in both cities expect demand of most use functions to increase by 2040, especially demand for thermal energy extraction, recreation and transportation. Some identified novel demands, such as climate regulation and reuse of waste products from waterway maintenance. Increasing demand is mainly driven by urban growth, climate change and sustainability ambitions. This study found urban surface water uses that are usually not acknowledged in scientific literature on urban water management. This comprehensive overview supports planning, design, and maintenance of urban surface waters, laying the foundation for future research on supply and demand of urban water use functions.
\end{abstract}

Keywords Urban water resources management - Ecosystem services · Water use · Water demand · Amsterdam · Toronto

\section{Introduction}

Surface water is an important resource and part of the public space in urban areas. Water use will increase due to population growth in European and North-American cities. Urban surface

Supplementary Information The online version contains supplementary material available at https://oi. org/10.1007/s11269-020-02700-7.

E. S. van der Meulen

suzanne.vandermeulen@wur.nl

Extended author information available on the last page of the article 
water use may change with, for example, transformation of former industrial sites and harbour areas into residential areas and cultural hotspots (Bostonplans.org; portofrotterdam.com; Feilberg and Mark 2016). Recently, urban water quality has improved across Europe (EEA 2016) and North America (McPhearson et al. 2014), opening new opportunities to use these waters. Strategic planning, design and maintenance of urban surface water systems can be optimized by taking into account all relevant use functions. Here use functions refers to all human use of water bodies, and can be distinguished in extractions (e.g. water for drinking or fish for nutrition) and in situ uses (e.g. swimming or transportation). Scientific literature supports function-oriented water management, describing drivers of water demand and supply, and the effectiveness of measures to influence these. Literature from the field of urban water resources management (UWRM) usually focusses on water extractions by different sectors. UWRM thus neglects demand and supply of in situ water use and the extraction of materials from water bodies beyond water itself.

This study therefore provides a comprehensive overview of all use functions of urban surface water, based on literature and in-depth analyses for two cities: Amsterdam (The Netherlands) and Toronto (Canada). While many studies focus on water management challenges in water-scarce urban regions (e.g. Haak and Pagilla 2020), our research is focused on water-rich cities in the western world. We focus on areas where ample water and a relatively high water quality support a broad spectrum of water uses. Managing supply and demand of the water use functions is key to ensure and improve quality of life in these cities. This study provides a comprehensive perspective on urban water use by combining the fields of UWRM and Ecosystem Services. Besides a theoretical overview of potential uses of urban water, we reveal actual use of these waters in two cities and the expected changes in demand by 2040 .

\section{Conceptual Approach}

We integrate knowledge from two scientific fields to develop a comprehensive understanding of urban surface water uses: UWRM and Ecosystem Services (ESS). The concepts of integrated and sustainable UWRM promote holistic management of all parts of the urban water cycle (Kirshen et al. 2018). These concepts also link water management and spatial planning, and integrate natural water bodies and technical infrastructures (Feilberg and Mark 2016; Hering and Vairavamoorthy 2018). Moreover, sustainable UWRM includes both quantitative management of water supply and water quality management considering the intended use (Hering and Vairavamoorthy 2018). In most UWRM literature on water supply and demand, water use is described as withdrawal for uses that are defined like agriculture; environment; urban or municipal water; or residential, domestic or household use and industrial water (Padowski and Gorelick 2014; Sharvelle et al. 2017; Ghavidelfar et al. 2017; Ali et al. 2017; Giacomoni and Berglund 2015; Exall and Vassos 2012; Haak and Pagilla 2020).

The ESS field provides a broader view on urban water use. ESS explains how ecosystems provide goods and services that are used by humans and contribute to their wellbeing and welfare (WRI 2003). The Common International Classification of Ecosystem Services (CICES) distinguishes three main categories of ESS: Provisioning, Regulating \& Maintenance and Cultural (www.cices.eu). A few studies provide information about potential uses of urban surface water (Blicharska and Johansson 2016; Haase 2015), urban lakes (Hossua et al. 2019) or the entire urban water system (Garcia et al. 2016). Maes et al. catalogued suitable indicators for mapping and assessing ESS in freshwater ecosystems (Maes et al. 2014) and urban 
ecosystems (Maes et al. 2016). For urban ecosystems, we selected information on the service providing units watersheds, water bodies, wetlands or waterways from their publication. A similar approach was performed for a publication on ESS in New York City (McPhearson et al. 2014). While most publications provide a theoretical overview of ESS, Person (2012) gives some concrete examples of actual use of urban ponds. Habitat or ecological functions (Blicharska and Johansson 2016; Garcia et al. 2016) influence the potential of ecosystems to deliver services (Potschin and Haines-Young 2011). If natural ecosystems are used by humans, this is included in our study as a specific use function. Nature in itself is not a human use function and is therefore not included in this study.

We identify some additional functions that are usually not included in UWRM or ESS studies. While not included in CICES, we include spatial use of water as carrier for human activities (Haines-Young and Potschin 2018), with water transportation (Haase 2015; Van der Meulen et al. 2016) and floating housing being well-known examples of urban water uses. Similarly, we include energy-related uses including thermal energy extraction (TEE) from surface water (Laanearu et al. 2017), energy production from salinity gradients (Swinkels et al. 2010), and kinetic energy like hydropower.

Based on literature and practical knowledge, we compiled a long list of potential use functions (Table 1). The main structure is based on the three CICES sections and an additional section covering spatial use of water. Online Resource 1 provides a detailed explanation for each use function. Within categories, use functions are differentiated to an appropriate level to prevent overlooking functions and to differentiate use functions with different water quality requirements. In this way, the list can support assessment of potential supply of the use functions.

\section{Method}

\subsection{Study Areas}

Toronto, Canada and Amsterdam, The Netherlands are intermediate sized cities with significant amount of surface water. They provide the opportunity to assess a wide array of water body types, water uses and water users. Both cities face densification. Former industrial harbour areas are redeveloped into new residential, cultural, leisure, and business areas. The cities are located on different continents, have different climates and represent varying geographic characteristics, thus broadening the study's validity (Table 2).

Toronto lies on the shores of Lake Ontario, a fresh-water lake with a surface area of $18,960 \mathrm{~km}^{2}$ and maximum depth of $244 \mathrm{~m}$ (EPA 2019). The city's hillsides are covered by river and creek watersheds that discharge into Lake Ontario. Other urban surface water bodies include storm water ponds and aesthetic ponds. Amsterdam is situated in a low delta area. Water enters the city through channelized rivers and large canals and, depending on tide, water is discharged through a large canal into the North Sea. The city contains a fine network of connected smaller canals, ponds and five deep (35 m) lakes (AGV 2014), relics of sand excavation. Amsterdam borders lake IJmeer with a $80 \mathrm{~km}^{2}$ surface and $2.6 \mathrm{~m}$ depth (Rijkswaterstaat 2019).

Toronto is assigned as Area of Concern according to the Great Lakes Water Quality Agreement (TRCA 2019). Road salt-related chloride issues are persistent while the situation for nutrients, faecal pollution and habitat diversity is locally improving (Dahmer et al. 2018; Edge et al. 2018; Howell et al. 2018; TRCA 2019). Chemical and ecological water quality in 
Table 1 Potential use functions of urban surface water. Short notations are used in graphs and tables

\begin{tabular}{|c|c|c|}
\hline Section & Category & Use function (short notation) \\
\hline \multirow[t]{15}{*}{ Provisioning } & \multirow[t]{4}{*}{ Nutrition } & Fishing for consumption (Fishing) \\
\hline & & $\begin{array}{l}\text { Catch of other surface water-related animals } \\
\text { for consumption (Other animals) }\end{array}$ \\
\hline & & $\begin{array}{l}\text { Harvest of aquatic plants or algae for consumption } \\
\text { (Plants or algae) }\end{array}$ \\
\hline & & $\begin{array}{l}\text { Water extractions for drinking water production } \\
\text { (Drinking water) }\end{array}$ \\
\hline & \multirow{6}{*}{$\begin{array}{l}\text { Water extraction for } \\
\text { non-drinking purposes }\end{array}$} & For irrigation of crops (Irrigation agriculture) \\
\hline & & For irrigation of other vegetation (Irrigation other) \\
\hline & & For industrial processes \\
\hline & & For fire-fighting \\
\hline & & For filling ponds \\
\hline & & For other non-drinking purposes (Other) \\
\hline & \multirow[t]{2}{*}{ Other materials } & Harvest of biomass for non-food purposes (Biomass) \\
\hline & & Extraction of abiotic materials (Abiotic materials) \\
\hline & \multirow[t]{3}{*}{ Energy } & Thermal energy extraction (Thermal energy/TEE) \\
\hline & & $\begin{array}{l}\text { Energy production using salinity gradient in water } \\
\text { (Energy salinity) }\end{array}$ \\
\hline & & Energy production using kinetic energy (Energy kinetic) \\
\hline \multirow{4}{*}{$\begin{array}{l}\text { Regulation \& } \\
\text { maintenance }\end{array}$} & \multirow[t]{4}{*}{ Regulation \& maintenance } & Managing water quality \\
\hline & & Managing water quantity \\
\hline & & Global climate regulation \\
\hline & & Local climate regulation \\
\hline \multirow[t]{8}{*}{ Cultural } & \multirow[t]{6}{*}{ Recreation } & Primary contact recreation (Primary contact) \\
\hline & & Secondary contact recreation (Secondary contact) \\
\hline & & Recreational boating (Boating) \\
\hline & & Sport fishing \\
\hline & & Hunting aquatic animals (Hunting) \\
\hline & & $\begin{array}{l}\text { Enjoying a landscape characterized by surface } \\
\text { water } \\
\text { (Landscape) } \\
\text { Ice-skating }\end{array}$ \\
\hline & \multirow{7}{*}{$\begin{array}{l}\text { Spiritual \& symbolic } \\
\text { interactions }\end{array}$} & Designation of cultural heritage value (Cultural heritage) \\
\hline & & Religious use \\
\hline \multirow[t]{5}{*}{ Space } & & Building on water (Building) \\
\hline & & Under water storage/infrastructure (Under water storage) \\
\hline & & Transporting goods \\
\hline & & Transporting persons \\
\hline & & Using water as a barrier (Physical barrier) \\
\hline
\end{tabular}

Amsterdam is generally "bad" to "moderate" according to European Water Framework Directive water quality classification (AGV 2018; HHNK 2018; Ministerie van Infrastructuur en Milieu 2018). Chemical pollution problems are persistent while faecal pollution and eutrophication are locally declining (AGV 2015).

\subsection{Documents Analysis and Interviews}

To verify actual use of urban surface water, water-related policy documents and technical reports were analysed from all relevant authorities involved in water management and spatial 
Table 2 Characteristics of study sites. Tav.: average temperature, Prec.: precipitation (Beck et al. 2018; City of Toronto 2019; Gemeente Amsterdam 2018; Metropoolregio Amsterdam et al. 2018; Statistics Canada and Ontario Ministry of Finance 2018; Wang et al. 2015)

\begin{tabular}{|c|c|c|}
\hline Characteristics & Toronto & Amsterdam \\
\hline Geography & $\begin{array}{l}\text { Hills along Lake Ontario, } \\
1.7 \% \text { water + Lake Ontario }\end{array}$ & $\begin{array}{l}\text { Low land area } \\
25-35 \% \text { water }+ \text { adjacent lakes and } \\
\text { waterways }\end{array}$ \\
\hline Surface water & $\begin{array}{l}\text { Rivers, creeks, shallow and } \\
\text { deep lakes, ponds (fresh water) }\end{array}$ & $\begin{array}{l}\text { Rivers, canals, shallow and deep lakes, } \\
\text { ponds (fresh to brackish water) }\end{array}$ \\
\hline Population density & 4,651 per $\mathrm{km}^{2}$ (land area) & $\begin{array}{l}3,850 \text { per } \mathrm{km}^{2} \text { (total surface area) } \\
5,178 \text { per } \mathrm{km}^{2} \text { (land area) }\end{array}$ \\
\hline Population 2018 & $\begin{array}{l}\text { City: } 2.96 \mathrm{mln} \\
\text { Greater Toronto Area (GTA): } 6.3 \mathrm{mln}\end{array}$ & $\begin{array}{l}\text { City: } 854,047 \\
\text { Metropolitan region (MRA): } 2,5 \mathrm{mln}\end{array}$ \\
\hline Population 2040 & $\mathrm{GTA}+52 \%$ & City $+18 \%$, MRA $+13 \%$ \\
\hline Climate & $\begin{array}{l}\text { Warm-summer humid continental climate } \\
\mathrm{T} \text { max. }-0.7^{\circ} \mathrm{C}(\mathrm{Jan}) \text { to } 26.6^{\circ} \mathrm{C}(\mathrm{Jul}) \\
\text { Precipitation } 831 \mathrm{~mm}\end{array}$ & $\begin{array}{l}\text { Moderate sea climate } \\
\mathrm{T} \text { max. } 5.8^{\circ} \mathrm{C} \text { (Jan) to } 22.1{ }^{\circ} \mathrm{C} \text { (Aug) } \\
\text { Precipitation } 897 \mathrm{~mm}\end{array}$ \\
\hline $\begin{array}{l}\text { Climate change } \\
\text { towards } 2050\end{array}$ & $\begin{array}{l}\text { Tav. }+4.0 \text { to } 4.7^{\circ} \mathrm{C} \\
\text { Prec. }+4.6 \text { to } 10.2 \% \\
\text { Intensity of rainfall storms increase }\end{array}$ & $\begin{array}{l}\text { Tav. }+1 \text { to } 1.5{ }^{\circ} \mathrm{C} \\
\text { Prec. }+4.5 \text { to } 5.7 \% \\
\text { Frequency and intensity of rainstorms } \\
\text { increase; water deficit in spring and } \\
\text { summer equal or increase }\end{array}$ \\
\hline
\end{tabular}

planning in the study areas. The documents were scanned for evidence of urban surface water use for the functions in the long list (Table 1). For use functions that were not mentioned in the policy documents, additional information sources have been searched in Scopus, Google and Deltares' and Wageningen University's libraries using the specific use function or 'water' in combination with the study areas or their region as keywords.

For several use functions, like smaller water extractions, current use is not documented; in other cases use data are more than five years old. For most use functions, future demand is not documented. Therefore, we conducted structured in-depth interviews with local water managers and spatial planners to check the validity of older documented information and to retrieve non-documented information on water use and future demand towards 2040.

Eleven participants, 6 in Amsterdam and 5 in Toronto, were interviewed individually in July-October 2019. They represent all authorities involved in water management and have supplementary knowledge on water use based on their different positions and fields of expertise. Six interviewees live in Amsterdam or Toronto. Anonymized transcripts are used for analysis. See Online Resource 2 for more details on the interview procedure.

\section{Results}

\subsection{Current Use}

Urban surface water in Toronto and Amsterdam is used for a broad range of functions (Fig. 1). Data on specific uses from the analysed documents and the interviews is provided in Online Resource 3. 
Surface water is used for several categories of provisioning functions (Fig. 1). Nutrition is extracted as locally caught fish in both cities. In Toronto, Lake Ontario is the main source of drinking water; in Amsterdam, surface water is not used for this purpose. In both cities, surface water is extracted for irrigation of food crops and other vegetation. Water extractions for other purposes are less frequently documented. Extraction of other materials for non-consumption purposes is uncommon. However, there is an experiment in Amsterdam with bio-composite production from mowed aquatic plants. In both cities, TEE from deep lakes is used for cooling office buildings. In Amsterdam, surface water from deep and shallow lakes, rivers and canals is also used for industrial cooling, for heating and cooling of houses or for cooling of bridges to prevent expansion in summer.

Surface water bodies are intentionally used for water regulation and maintenance in both cities, but in different ways. Storm water management ponds are widely applied in Toronto to manage runoff water quality and quantity before these enter rivers or creeks. Amsterdam's surface water network is actively managed to control water discharge and retention. The water inflow from Lake IJmeer and a large canal into the water system of Amsterdam is regularly increased to mitigate inflow of saline water through another canal that connects Amsterdam and the sea or through seepage water.

Surface water use for cultural functions mainly involves recreational activities. Amsterdam and Toronto have officially designated areas in lakes for primary contact recreation. Especially in Amsterdam, swimming also occurs outside these areas in all types of water. Secondary contact recreation like canoeing, rowing and sailing takes place on various water bodies in both cities. In Toronto, these activities are mostly concentrated on Lake Ontario. Sport fishing is also popular in both cities, and urban dwellers enjoy surface water as an important landscape element. Recreation along the water is common in both cities, but this type of use is not extensively documented. Although winter temperatures usually do not allow for it, ice-skating

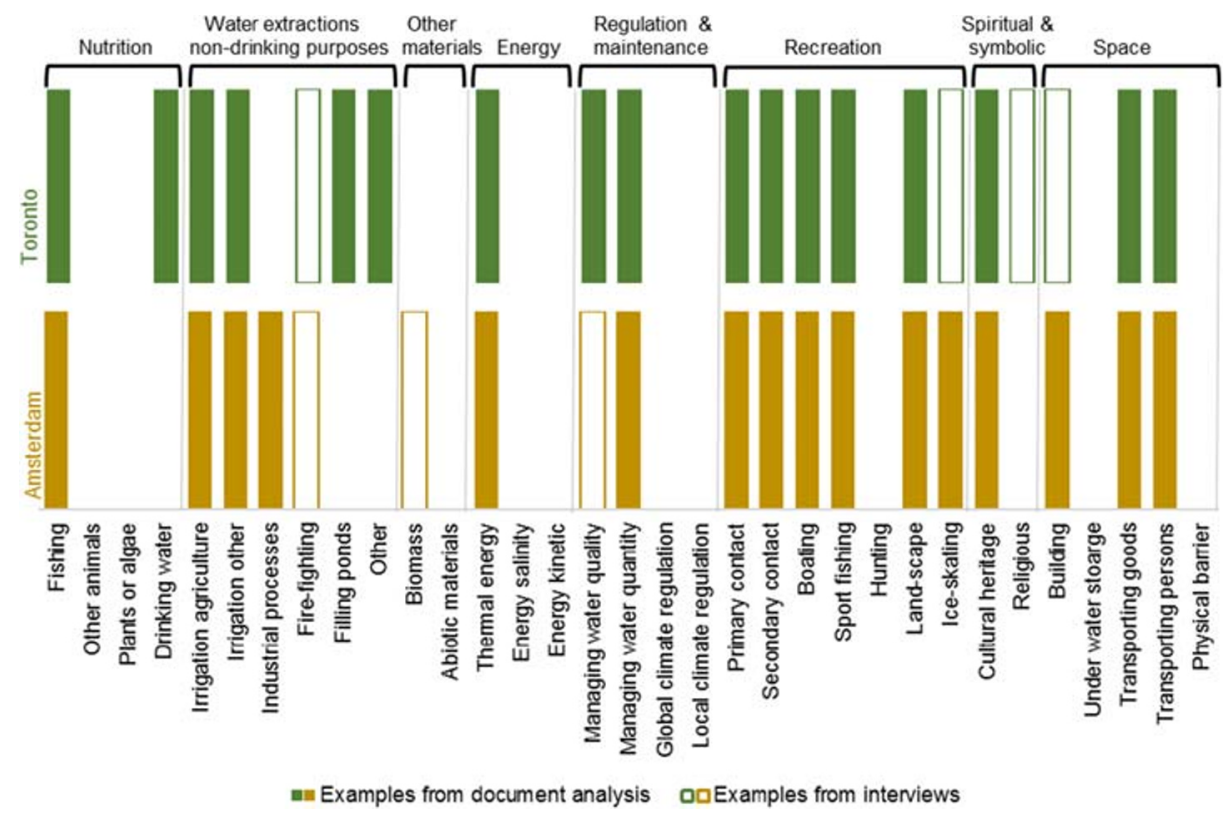

Fig. 1 Current use of urban surface water in Toronto (above) and Amsterdam (below) 
is considered an important use function of Amsterdam's canals. No documented examples were found for ice-skating on Toronto's surface waters. Interviewees mentioned that iceskating does happen on some ponds although it is not allowed. Spiritual and symbolic use of surface water is more prevalent in Toronto than in Amsterdam. Symbolic use is demonstrated by the World Heritage status of Amsterdam's inner canal system and designation of Humber river in Toronto as Canadian Heritage River. Religious use of surface water is not documented, although one interviewee in Toronto observed religious or funeral ceremonies along the shores and on the water of Lake Ontario, and at some ponds.

The space provided by water is intensively used in Amsterdam to accommodate houseboats and other floating buildings like bicycle shelters. In Toronto, this use of the water surface is rare. The few houseboats that interviewees observed are not mentioned in water management documents. Surface water in both cities plays an important role in transportation of goods and persons. In Toronto, Lake Ontario accommodates international cargo transport lines and in Amsterdam the larger canals, rivers and Lake IJmeer provide important waterways for national and international transportation of goods. The same waters are also used by cruise ships. Waterborne public transport is mainly focussed on transporting pedestrians or cyclists and is limited to destinations that cannot be reached otherwise.

Interviewees were asked to add to the list of use functions. Several interviewees stated that this list was already more extensive than expected, including use functions that they did not think of before. Six interviewees suggested to include the nature or habitat function. One interviewee mentions that local surface water is also used as a scientific research object.

\subsection{Future Trends in Demand}

For most provisioning use functions, demand is expected to remain equal or increase and new uses may emerge (Fig. 2). An exception to this pattern is that interviewees in Toronto foresee equal or declining demand for water extractions for non-drinking purposes. Notably, interviewees have most information and relatively high certainty about extractions for drinking water, irrigation, and TEE (Fig. 3). Toronto's increase in TEE demand is limited mainly to cooling of buildings with Lake Ontario water. Potential emerging demand is reported for consumption of undesired species, like exotic Crayfish, in both cities. Emerging demand is also reported for non-edible use of biomass and abiotic waste products from waterway maintenance works such as dredged sediments or mowed aquatic plants. Another emerging demand in Amsterdam is surface water extraction for decentralized drinking water production. Local water managers receive requests by private parties, such as a cultural site, who want to produce their own drinking water from local surface water. Most interviewees consider the local water system unsuitable for energy production by using kinetic energy or osmotic processes relying on salinity gradients. Some interviewees think that demand may also emerge for these activities.

In the category maintenance and regulation functions, several interviewees in both cities expect increasing demand for water quality and quantity regulation. In Toronto, however, demand for storm water ponds may diminish or decline due to lack of space, high land prices and the preference for low impact development to reduce storm water runoff. Most interviewees have no information about the use of surface water to influence global climate. For the intentional use of surface water to influence local climate, all interviewees from Amsterdam and one in Toronto report emerging demand. 


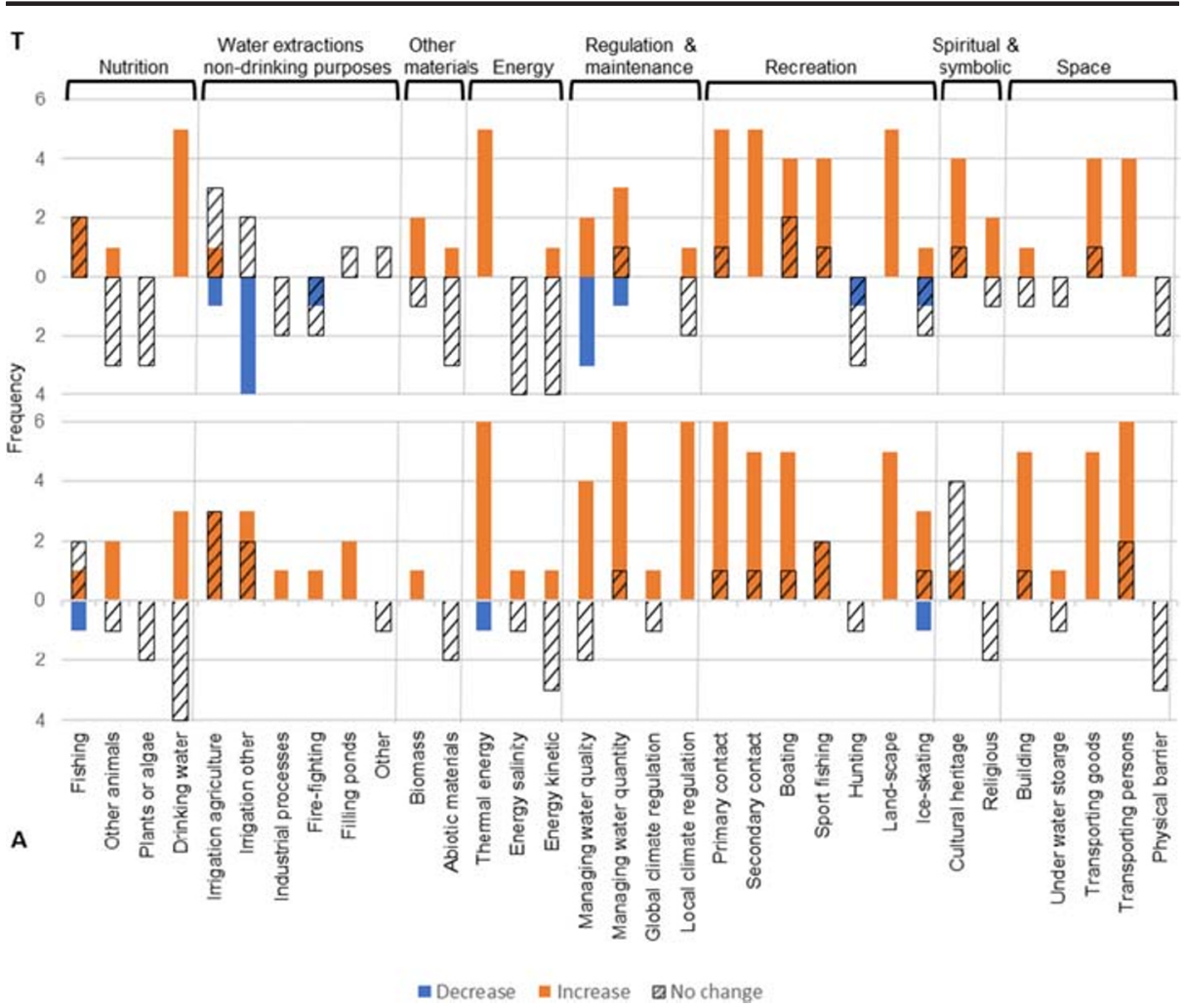

Fig. 2 Expected trends in demand by 2040 in Toronto (above) and Amsterdam (below). 'No change' bar directed downwards: function is currently not used and interviewees expect no demand in the future. 'No change' bar directed upwards: function is currently being used and interviewees expect no change in demand. Frequency of a trend may be higher than the number of interviewees, since some mention two trends for the same use function, e.g. 'equal or increase'

Demand for most cultural functions is expected to increase, especially for recreation. In the case of primary contact recreation, this is not limited to officially designated swimming areas; especially in Amsterdam demand for swimming grows for all kinds of waters. In Toronto, the increasing demand for secondary contact recreation and boating is mainly foreseen on Lake Ontario since boating opportunities on rivers and creeks are limited due to low water levels. Hunting is expected to remain absent and not allowed in both cities. Some interviewees in both cities expect demand for ice-skating to decrease due to higher temperatures. Spiritual and symbolic interactions with the urban surface water system seem to become more important in Toronto than in Amsterdam. In Toronto, several interviewees report increasing demand for religious practices.

Spatial use of surface water for transportation is expected to increase in both cities. Increasing demand for transport of goods in Toronto relates to local and international transport on Lake Ontario. In Amsterdam, national and international transportation will increase through the large waterways and local transportation via smaller canals. Demand for transportation of passengers will grow mainly due to intensification of cruises in both cities. Interviewees also expect more intense use of the few existing public transport lines and possibly a few new routes in specific areas where waterborne transport is faster than road or rail. Growing demand for floating buildings or other structures is mainly limited to Amsterdam. Under-water space is currently unused in both cities, and most interviewees have no information about future 


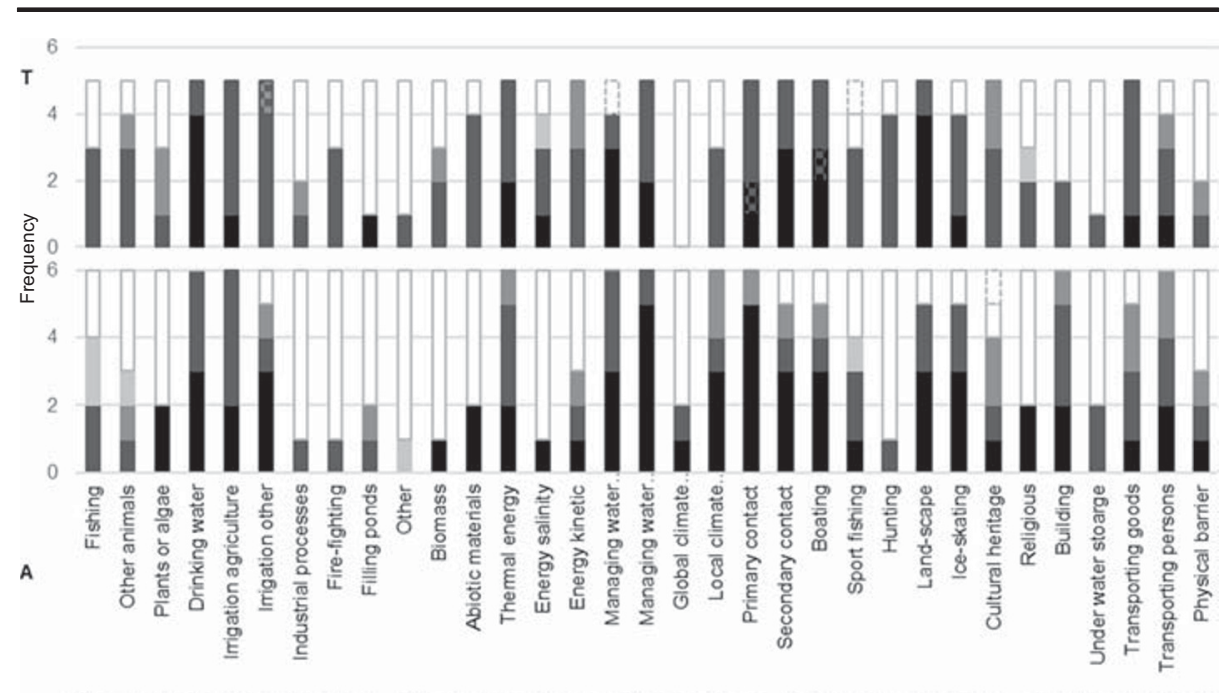

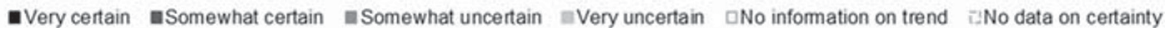

Fig. 3 Degree of certainty that interviewees have for the trend in demand and the number of interviewees that have no information about specific use functions. T: Toronto, A: Amsterdam. Checker board pattern: interviewee mentioned different levels of certainty for different aspects of a use function

demand for this. One interviewee in Amsterdam reports interest to lay electricity cables at the bottom of large canals as opposed to the subsurface where space is becoming scarce. Finally, the use of water as a physical barrier is considered to be outdated, and interviewees do not expect demand to emerge before 2040 .

\subsection{Drivers Explaining Future Increasing Demand}

Interviewees indicated an overall increase in demand for urban surface water use by 2040. The most frequently mentioned categories of drivers for both cities are urban growth, climate change, sustainability ambitions and social trends (Table 3). Urban growth and redevelopment is expected to result in increased demand for nearly all categories of use functions, especially due to an increasing number of users (Online Resource 4). Densification leads to a higher concentration of users and a lack of space on land, both of which drive increasing demand for spatial water uses. Redevelopment near water improves accessibility of the water and introduces new users. Climate change influences demand for several categories of use functions. Drought may increase demand for some water extractions, especially in Amsterdam, and more extreme rainfall patterns drive demand for water quality and quantity regulation. Temperature increase mainly influences demand for local climate regulation and recreation. Sustainability ambitions mainly drive demand for TEE and transportation. Circularity ambitions drive emerging demand for beneficial use of biotic or abiotic waste materials from waterway maintenance works. In Amsterdam, the ambition to reduce drinking water consumption may lead to increasing demand for surface water as an alternative source for irrigation or firefighting. Social trends are mainly expected to drive demand for nutrition, recreation and transportation of persons. For example, preferences for local products may cause an increase in fishing for consumption or decentralized drinking water production.

Some drivers are frequently reported in only one city. In Toronto, several interviewees expect that water quality improvements will result in increased demand for nutrition and 


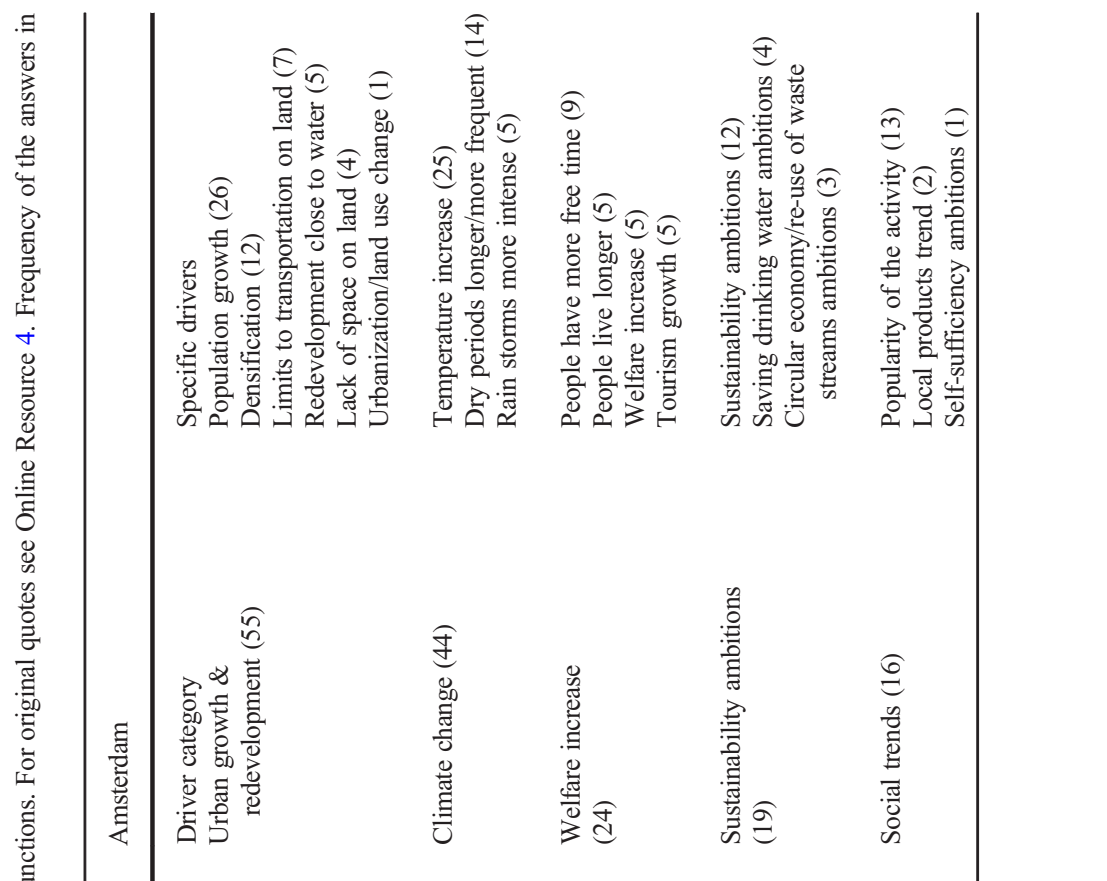


recreation. Only in Amsterdam, welfare growth is frequently mentioned as driver for increased demand for recreation and cruises. Besides the six main categories of drivers, there are less frequently mentioned drivers like intentions to save on costs, local developments in specific sectors or infrastructure and technological developments (Online Resource 5).

Changes in demand for specific use functions are the result of a combination of drivers. This is illustrated for TEE and recreation. Increasing TEE demand is mainly driven by sustainability ambitions to reduce fossil fuel use for cooling or heating. Cooling demand may increase due to climate change, to local growth in specific sectors like energy production and data centres, or to opportunities to link demand and supply due to redevelopment near water. TEE demand is further pushed by local developments that differ per city. Demand for recreation increases mainly due to population growth and transformation of former industrial areas near water into residential and cultural hotspots. Demand is further pushed by an increasing need for warm-weather recreation due to climate change and by the popularity of water sports and other outdoor activities. Locally, welfare growth results in more people that have time and/or financial resources for water recreation. Furthermore, water quality improvements and measures may improve opportunities for recreation.

\section{Discussion}

\subsection{Structured Assessment Reveals Broad Use of Urban Surface Water in Theory and Practice}

By integrating knowledge on UWRM and ESS, we compiled a comprehensive long list of potential use functions of urban surface water (Table 1). Our analysis of cities in NorthAmerica and Europe shows that actual use is even broader than what is usually included in scientific literature on urban water use (e.g. Haase 2015; Padowski and Gorelick 2014; Persson 2012). Most use functions involve in situ use of urban surface water rather than water extractions.

Document analysis in Toronto and Amsterdam revealed that surface water in both cities is used for a variety of functions related to nutrition, energy, water regulation, recreation, symbolic use, transportation and space for buildings (Fig. 2). For several use functions from the long list, no examples of actual use were found in reviewed documents. However, this does not ensure that water is not used for these functions. This information gap was resolved to a great extent by interviewing spatial planners and water managers. Their professional knowledge, and in many cases additional local knowledge as a citizen, resulted in a more complete overview of actual urban surface water use. The uses that were uncovered in this way, like water extractions for fire-fighting and religious use, probably are relatively small scale applications. This assessment of actual use of surface water provides additional insights beyond those estimating ESS provisions using modelling (e.g. Grêt-Regamay et al. 2020).

There are many similarities between surface water use in Amsterdam and Toronto (Fig. 2). The most notable differences may be explained by characteristics of the local water system (Table 2). The presence of Lake Ontario provides Toronto with a large reservoir of drinking water, while the smaller water bodies in Amsterdam are less reliable than sources outside the city. Spatial use of the water's surface is more common in Amsterdam than in Toronto. Amsterdam's location in a low delta area with calm waters and a dense network of canals across the entire city provides many opportunities for spatial uses like floating buildings. 
Toronto's topography with mainly free flowing rivers and creeks and a city centre with less open surface water area provides less opportunities for this type of water use. It is plausible that the spatial use of urban surface water will generally be higher for cities with a relatively large surface area of calm waters.

\subsection{Future Trends by 2040: Intensification of Urban Surface Water Use}

In-depth interviews with water managers and spatial planners provided insight in changes in demand for urban surface water before 2040 in Amsterdam and Toronto. The results reveal three main patterns in both cities: 1) increasing demand for many use functions; 2) high confidence in expectations on increasing demand for TEE, different types of recreation and transportation; 3) broadening of the range of uses through emerging demand for new use functions (Figs. 2 and 3). This reveals that urban surface water use can be expected to further intensify.

Changes in demand may seem less relevant for use functions for which only one or two interviewees foresee a change. However, interviewees are sometimes certain about the trend based on their contacts with stakeholders. Such situations often involve functions that are currently not, or not widely, used like extraction of biomass for non-consumption purposes or local climate regulation. It seems logical that fewer interviewees have knowledge about future demand for these use functions than for more common functions.

Interviewees sometimes report conflicting trends, which shows that visions on specific use functions vary among the stakeholders. However, a high degree of consistency exists for the three main patterns in future demand within and between the two cities. It is therefore expected that another group of professionals covering all relevant fields of expertise would validate these patterns.

\subsection{Common Drivers of Increasing Demand}

The main drivers of demand identified by interviewees are developments applicable to other western, water-rich cities (Table 3). For example, urban population growth, densification and redevelopment near water are common trends (e.g. Feilberg and Mark 2016; UN 2018). Increasing temperatures, more extreme rain storms and drought periods are common aspects of climate change in the Northern Hemisphere (Meehl et al. 2007). Sustainability ambitions are set in international agreements and policies such the Paris Agreement (UN 2015) and the European Circular Economy Action Plan (EC 2020). The widespread occurrence of these developments indicates that the main trends in demand as identified in Toronto and Amsterdam are likely relevant to other comparable cities.

Some reported drivers are known from literature. For example, population growth is known to be the key driver for current and future projected participation rates in outdoor, water-related recreation (Bowker et al. 2012; Cordell 2012). Blue-green infrastructure is widely proposed as climate adaptation measure (Altvater et al. 2011; WHO 2017), which confirms our finding of increasing demand for water and climate regulation functions as a response to climate change. The city of Copenhagen, Denmark provides an example outside our study areas where water quality improvement led to increased recreational water use, even for swimming (EEA 2016). Beyond known drivers, our study provides insight into combinations of drivers that cause trends in demand specifically for urban surface water use functions, including less studied use functions like TEE. 
While more universal developments strongly impact demand for urban surface water use, specific local circumstances and developments are decisive in some cases. For example, differences in developments in Amsterdam and Toronto result in differences in demand for water extractions. Interviewees in Toronto expect decreasing demand, emphasizing that farmers and golf courses, the main users of extracted surface water, leave the city. Conversely, some interviewees in Amsterdam see new water users, such as hydrogen factories, moving into the city. Another example is that more interviewees in Amsterdam than in Toronto foresee growing demand for beneficial use of waste products from waterway maintenance works. This difference may be explained by the larger amount of waterways in Amsterdam requiring dredging and mowing to facilitate navigation and water discharge. Exploring more cities across Europe and North America using the method developed in this study will further highlight universal and context dependent trends in demands for urban water use

\subsection{Implications for Future Research and Water Management}

The results of this study motivate a broader perspective on urban surface water use in science and water management. Our long list of potential use functions can guide future research on supply and demand. Interviewees indicated that they would not have thought about some use functions spontaneously even though they did have information about them (Section 4.1). This demonstrates that using the list helps to prevent overlooking use functions.

Several authors (Section 2) and interviewees suggest to include ecological functions, or 'nature' or 'habitat functions', to the long list. However, ecological functions do not comply with the scope of this study on human use functions and thus were not addressed. Assessment of ecological ecosystem quality can be performed in parallel to research on demand and potential supply of human use functions. Such an integrated analysis enables assessment of trade-offs between ecological water quality and the potential supply of human use functions, supporting management choices by water managers and spatial planners. In some ESS studies, authors include the role of water bodies as an object of scientific research and educational activities. Only one interviewee mentioned scientific research as a use function. This indicates that scientific and educational use of surface water have low relevance for practical urban water management.

For three potential functions from the list, no evidence was found for current use or future demand in the study areas: harvesting aquatic plants or algae for consumption, hunting and water as a physical barrier. Additional assessments in other cities may reveal the relevance of these functions in an urban context.

\section{Conclusions}

By combining UWRM and ESS literature, we developed a comprehensive overview of potential use functions of urban surface water. This overview contains use functions that are often lacking in UWRM literature, as many studies are focussed on water extractions. Analysis of actual use of surface water systems in two cities demonstrates that many use functions involve in situ use rather than water extractions.

The study also reveals that demand for existing and new use functions is expected to increase. This will result in an increased pressure on urban surface water systems to deliver multiple services. These findings motivate a broader perspective on the use of urban surface 
water in science and in water management. The overview of potential use functions that was developed in this study can guide future research on supply and demand of these functions.

Author Contributions All authors contributed to the study conception and design. Data collection and analysis by Suzanne van der Meulen. First draft manuscript by Suzanne van der Meulen; all authors commented on previous versions. All authors read and approved final manuscript and have agreed to submit the manuscript to this journal.

Funding AMS and Deltares.

Data Availability Online Resources.

\section{Compliance with Ethical Standards}

\section{Conflicts of Interest None.}

Code Availability Not applicable.

Open Access This article is licensed under a Creative Commons Attribution 4.0 International License, which permits use, sharing, adaptation, distribution and reproduction in any medium or format, as long as you give appropriate credit to the original author(s) and the source, provide a link to the Creative Commons licence, and indicate if changes were made. The images or other third party material in this article are included in the article's Creative Commons licence, unless indicated otherwise in a credit line to the material. If material is not included in the article's Creative Commons licence and your intended use is not permitted by statutory regulation or exceeds the permitted use, you will need to obtain permission directly from the copyright holder. To view a copy of this licence, visit http://creativecommons.org/licenses/by/4.0/.

\section{References}

AGV (Hoogheemraadschap Amstel Gooi en Vecht) (2014) Watergebiedsplan Amsterdam Nieuw-West, March 2014

AGV (Hoogheemraadschap Amstel Gooi en Vecht) (2015) Waterbeheerplan 2016-2021; Waterbewust en waterrobuust. Available at: https://www.agv.nl/siteassets/onze-taken/waterbeheerplan/wat-waterbeheerplan2016-2021-interactief.pdf

AGV (Hoogheemraadschap Amstel Gooi en Vecht) (2018) KRWfactsheet_OW_11. Available at: https://www. waterkwaliteitsportaal.nl/Beheer/Data/Publiek?viewName=Factsheets\&year=2018\&month=December

Ali AM, Shafiee ME, Berglund EZ (2017) Agent-based modeling to simulate the dynamics of urban water supply: Climate, population growth, and water shortages. Sustain Cities Soc 28:420-434

Altvater S, McCallum S, Prutsch A et al (2011) Identification of the most appropriate measures that could address each threat, for implementation in the time frame 2013-2020 "Climate Proofing" of key EU policies: report for task 2

Beck HE, Zimmermann NE, McVicar TR et al (2018) Present and future Köppen-Geiger climate classification maps at 1-km resolution. Sci Data 5. https://doi.org/10.1038/sdata.2018.214

Blicharska M, Johansson F (2016) Urban ponds for people and by people. In: Francis RA, Millington JDA, Chadwick MA (eds) Urban landscape ecology: science, policy and practice. Routledge, Abingdon, pp 164 180

Bowker JM, Askew AE, Cordell HK et al (2012) Outdoor recreation participation in the United Statesprojections to 2060: a technical document supporting the Forest Service 2010 RPA Assessment. U.S. Department of Agriculture Forest Service, Southern Research Station, Asheville

City of Toronto (2019) Toronto at a glance. https://www.toronto.ca/city-government/data-research-maps/torontoat-a-glance/. Accessed 20 Aug 2019

Cordell HK (2012) Outdoor recreation trends and futures: a technical document supporting the Forest Service 2010 RPA Assessment U.S. Department of Agriculture Forest Service, Southern Research Station, Asheville 
Dahmer SC, Matos L, Morley A (2018) Preface-Restoring Toronto's waters: Progress toward delisting the Toronto and Region Area of Concern. Aquat Ecosyst Health Manag 21:229-233. https://doi.org/10.1080 $/ 14634988.2018 .1491759$

EC (European Commission) (2020) A new circular economy action plan; for a cleaner and more competitive Europe. COM(2020) 98 final. Brussels, 11.3.2020

EEA (European Environment Agency) (2016) Rivers and lakes in European cities; Past and future challenges. Luxembourg: Publications Office of the European Union, 2016, EEA report No 26/2016, ISSN 1977-8449, ISBN 978-92-9213-821-9, https://doi.org/10.2800/516136

Edge TA, Hill S, Crowe A et al (2018) Remediation of a beneficial use impairmentat Bluffer's Park beach in the Toronto area of concern. Aquat Ecosyst Health Manag 21:285-292. https://doi.org/10.1080 $/ 14634988.2018 .1497401$

EPA (Environmental Protection Agency) (2019) Physical features of the great lakes. https://www.epa. gov/greatlakes/physical-features-great-lakes. Accessed 20 Aug 2019

Exall K, Vassos TD (2012) Integrated urban water management: Water use and reuse. In: Zeman F (ed) Metropolitan sustainability: understanding and improving the urban environment. Elsevier Ltd., Amsterdam, pp 319-349

Feilberg M, Mark O (2016) Integrated urban water management: Improve efficient water management and climate change resilience in cities. In: Younos T, Parece T (eds) Sustainable water management in urban environments. The handbook of environmental chemistry, vol 47. Springer International Publishing Switzerland, Cham, pp 1-32. https://doi.org/10.1007/978-3-319-29337-0_1

Garcia X, Barcelóa D, Comas J et al (2016) Placing ecosystem services at the heart of urban water systems management. Sci Total Environ 563-564:1078-1085. https://doi.org/10.1016/j.scitotenv.2016.05.010

Gemeente Amsterdam (2018) Amsterdam in cijfers, Jaarboek 2018. https://data.amsterdam. nl/artikelen/artikel/jaarboek-amsterdam-in-cijfers-2018/a514cbe3-453c-4213-bdff-475898dc2a5a/

Ghavidelfar S, Shamseldin AY, Melville BW (2017) Future implications of urban intensification on residential water demand. J Environ Plan Manag 60:1809-1824. https://doi.org/10.1080/09640568.2016.1257976

Giacomoni MH, Berglund EZ (2015) Complex adaptive modeling framework for evaluating adaptive demand management for urban water resources sustainability. J Water Resour Plan Manag 141(11):04015024

Grêt-Regamay A, Galleguillos-Torres M, Dissegna A, Weibel B (2020) How urban densification influences ecosysten services - a comparison between a temperata and a tropical city. Environ Res Lett 15. https://doi. org/10.1088/1748-9326/ab7acf

Haak L, Pagilla K (2020) The water-economy nexus: a composite index approach to evaluate urban water vulnerability. Water Resour Manag 34:409-423. https://doi.org/10.1007/s11269-019-02464-9

Haase D (2015) Reflections about blue ecosystem services in cities. Sustain Water Qual Ecol 5:77-83. https://doi.org/10.1016/j.swaqe.2015.02.003

Haines-Young R, Potschin MB (2018) Common International Classification of Ecosystem Services (CICES) V5.1 and Guidance on the Application of the Revised Structure. www.cices.eu Accessed 11 Oct 2020.

Hering JG, Vairavamoorthy K (2018) Harvesting experience for Sustainable Urban Water Management. In: Biswas A, et al. (eds) Assessing global water megatrends, water resources development and management. Springer Nature Singapore Pte Ltd., , pp 61-75. https://doi.org/10.1007/978-981-10-6695-5_4

HHNK (Hoogheemraadschap Hollands Noorderkwartier) (2018) KRWfactsheet_OW_12 Hoogheemraadschap_Hollands_Noorderkwartier_2018-10-16-02-20-21, v3.63. Available at: https://www. waterkwaliteitsportaal.nl/Beheer/Data/Publiek?viewName=Factsheets\&year=2018\&month=December

Hossua C, Iojăa I-C, Onosea D et al (2019) Ecosystem services appreciation of urban lakes in Romania. Synergies and trade-offs between multiple users. Ecosyst Serv 37. https://doi.org/10.1016/j. ecoser.2019.100937

Howell ET, Dahmer SC, Chomicki KM et al (2018) Monitoring water quality on the central Toronto waterfront: Perspectives on addressing spatiotemporal variability. Aquat Ecosyst Health Manag 21:255-267. https://oi. org/10.1080/14634988.2018.1500060

Kirshen P, Aytur S, Hecht J et al (2018) Integrated urban water management applied to adaptation to climate change. Urban Clim 24:247-263. https://doi.org/10.1016/j.uclim.2018.03.005

Laanearu J, Borodinecs A, Rimeika M, Palm B (2017) A review on potential use of low-temperature water in the urban environment as a thermal-energy source. IOP Conference Series: Materials Science and Engineering 251. https://doi.org/10.1088/1757-899x/251/1/012054

Maes J, Teller A, Erhard M et al (2014) Mapping and assessment of ecosystems and their services. Indicators for ecosystem assessments under Action 5 of the EU Biodiversity Strategy to 2020, 2nd Report - Final. https://doi.org/10.2779/75203

Maes J, Zulian G, Thijssen M et al (2016) Mapping and assessment of ecosystems and their services. Urban ecosystems, 4th Report, Final. Luxembourg. https://doi.org/10.2779/625242 
McPhearson T, Hamstead ZA, Kremer P (2014) Urban ecosystem services for resilience planning and management in New York City. Ambio 43:502-515. https://doi.org/10.1007/s13280-014-0509-8

Meehl GA, Stocker TF, Collins WD et al (2007) Global climate projections. In: Solomon S et al (eds) Climate Change 2007: The physical science basis. Contribution of working group I to the fourth assessment report of the intergovernmental panel on climate change. Cambridge University Press, Cambridge

Metropoolregio, Amsterdam, Gemeente Amsterdam, Waternet, Waterschap Amstel Gooi en Vecht (2018) Ons klimaat verandert. http://klimaatverandering-mra.vormgeving.com/

Ministerie van Infrastructuur en Milieu (2018) KRWfactsheet_OW_80_Ministerie_van_Infrastructuur_en

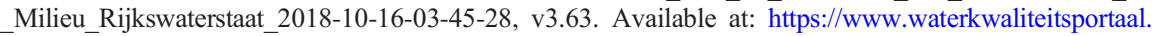
nl/Beheer/Data/Publiek?viewName=Factsheets\&year=2018\&month=December

Padowski JC, Gorelick SM (2014) Corrigendum: Global analysis of urban surface water supply vulnerability. Environ Res Lett 9. https://doi.org/10.1088/1748-9326/9/11/119501

Persson JJJ (2012) Urban lakes and ponds. In: Fairbridge RW (ed) Encyclopedia of earth sciences. pp 836-839. Springer, Dordrecht. https://doi.org/10.1007/978-1-4020-4410-6_15https://doi.org/10.1007/978-1-40204410-6_15

Potschin M, Haines-Young RH (2011) Ecosystem services: Exploring a geographical perspective. Prog Phys Geogr 35:575-594

Rijkswaterstaat (2019) IJmeer. https://www.rijkswaterstaat.nl/water/vaarwegenoverzicht/ijmeer/index.aspx. Accessed 20 Aug 2019

Sharvelle S, Dozier A, Arabi M, Reichel B (2017) A geospatially-enabled web tool for urban water demand forecasting and assessment of alternative urban water management strategies. Environ Model Softw 97:213228. https://doi.org/10.1016/j.envsoft.2017.08.009

Statistics Canada, Ontario Ministry of Finance (2018) Ontario population projections update, 2017-2041; Table 4: Historical and projected population by census division, selected years — reference scenario

Swinkels CM, Bijlsma AC, Hommes S (2010) Blue Energy Noordzeekanaal; Verkenning naar een Blue Energy centrale langs het Noordzeekanaal. Deltares, 2010. Document number: 1200339-007-VEB-0001. Available at: https://edepot.wur.nl/212388

TRCA (Toronto and Region Conservation Authority) (2019) Aquatic habitat Toronto; 5. Toronto and Region Area of Concern. https://trca.ca/conservation/aquatic-habitat-toronto/existing-conditions-habitat/\#area-ofconcern. Accessed 22 Aug 2019

UN (United Nations) (2015) Paris agreement. https:/unfccc.int/files/essential_background/convention/ application/pdf/english_paris_agreement.pdf

United Nations, Department of Economic and Social Affairs, Population Division (2018). The World's Cities in 2018_-Data Booklet. Document number: ST/ESA/SER.A/417. Available at: https://www.un. org/en/events/citiesday/assets/pdf/the_worlds_cities_in_2018_data_booklet.pdf

Van der Meulen ES, Braat LC, Brils JM (2016) Abiotic flows should be inherent part of ecosystem services classification. Ecosyst Serv 19:1-5. https://doi.org/10.1016/j.ecoser.2016.03.007

Wang X, Huang G, Liu J et al (2015) Ensemble projections of regional climatic changes over Ontario. Can J Clim 28:7327-7346. https://doi.org/10.1175/JCLI-D-15-0185.1

WHO (World Health Organization) (2017) Environment and health for European cities in the 21st century: making a difference. WHO Regional Office for Europe

WRI (World Resources Institute) (2003) Ecosystems and human well-being; a framework for assessment. Washington, D.C.

Publisher's Note Springer Nature remains neutral with regard to jurisdictional claims in published maps and institutional affiliations.

\section{Affiliations}

\section{E. S. van der Meulen ${ }^{1,2} \cdot$ N. B. Sutton ${ }^{2}$ - F. H. M. van de Ven ${ }^{1,3} \cdot$ P. R. van Oel ${ }^{4} \cdot$ H. H. M. Rijnaarts $^{2}$}

1 Urban Water and Subsurface Management, Deltares, Delft, The Netherlands

2 Environmental Technology, Wageningen University, Wageningen, The Netherlands

3 Water Resources Management, Delft University of Technology, Delft, The Netherlands

4 Water Resources Management, Wageningen University, Wageningen, The Netherlands 